Article

\title{
Yield Spread and Economic Policy Uncertainty: Evidence from Japan
}

\author{
Mei-Chih Wang ${ }^{1}$, Pao-Lan Kuo ${ }^{2, *}$, Chan-Sheng Chen ${ }^{2}$, Chien-Liang Chiu ${ }^{2}$ and \\ Tsangyao Chang ${ }^{3}$ \\ 1 Finance Faculty, Providence University, Taichung 43301, Taiwan; wangsona@gmail.com \\ 2 Department of Banking and Finance, Tamkang University, New Taipei 25137, Taiwan; \\ Johnson.c1002@gmail.com (C.-S.C.); 100730@mail.tku.edu.tw (C.-L.C.) \\ 3 Department of Finance, Feng Chia University, Taichung 40724, Taiwan; tychang@mail.fcu.edu.tw \\ * Correspondence: iampaulinekuo@gmail.com
}

Received: 28 March 2020; Accepted: 4 May 2020; Published: 25 May 2020

\begin{abstract}
In this paper, we adopt the nonlinear autoregressive distributed lags (NARDL) model extended by Shin et al. (2014) to investigate the relationship between the treasury yield spread and economic policy uncertainty (EPU) in Japan. This model helps us to explore the short- and long-run asymmetric reactions of explained variables through positive and negative partial sum decompositions of changes in the explanatory variable(s). In our research, the testing of the NARDL specification reveals the existence of a significant long-run asymmetric equilibrium between the yield spread and EPU in Japan. On the other hand, we find a significant positive nexus between the treasury yield spread and EPU reduction in the long run. We speculate that because of low inflation, a poor economic outlook and the low interest rate environment since 1990, financial agents are markedly sensitive to negative shocks resulting from EPU. This means that when facing a good economy, bond agents are quick to sell, especially with higher-risk long-term interest rate bonds. Meanwhile, because the Bank of Japan announced the Stock Purchasing Plan in October 2002 and from the point view of portfolio management, while the influence of a positive economic outlook dominates the negative outlook, flight from quality has no role in asset portfolio adjustment. The empirical implications are that the long history of unconventional monetary policy supports the demand for both bonds and stock markets. When taking the stock market into consideration, the correlations between the yield spread, EPU and stock market capture the full wealth effects of the low interest rate environment in Japan.
\end{abstract}

Keywords: nonlinear autoregressive distributed lags (NARDL) model; economic policy uncertainty (EPU); yield spread; unconventional monetary policy in Japan

\section{Introduction}

Traditionally, people rely on yield spreads as indicators for forecasting the future state of the economy and the probability of a recession [1,2]. Furthermore, when the yield curve is negative (that is, the long-term interest rates are lower than the short-term interest rates), there exists a high probability of negative or decreasing macroeconomic outlook [3]. However, some evidence shows that the forecasting ability of the yield curve is declining [4]. The weak performance of the yield curve may arise from the financial market's expectation, which regards future short- and long-term rates as a time variation in the term premium [2], meaning that the information contained in spreads may be ready to be adjusted. However, some studies have suggested mixed results for the information set of the Japanese yield for future recessions. Hirata and Ueda [5] found that, in Japan, the predictive contribution of the yield spread dominating the stock markets and other financial variables, though the predictive power of 
the Japanese yield spread, is not as strong as that of the US yield spread. Meanwhile, Hasegawa and Fukuta [6] revealed that because of the economic structure break in 1996 and the Asian Financial Crisis in 1998, the Bank of Japan (BOJ) started the longest period of unconventional monetary policy in the world, increasing market agents' demand for bonds; therefore, some of the forecasting ability of the Japanese yield spread has decreased.

Recently, research has tried to identify indicators other than treasury spreads as macroeconomic outlook forecasting tools. Based on Baker et al. [7], the Economic Policy Uncertainty (EPU) index is a good symbol for economic policy uncertainty, and this proxy mostly looks backward to past keywords used in news articles [8]. Many studies have speculated whether an increase in policy uncertainty would signify the coming of a recession [9-11]. Bloom [12], Baker et al. [7], Leduc and Liu [13], and Charles et al. [14] show that an increase in uncertainty first leads to a drop in all macroeconomic series.

Japan is the country that has adopted the longest period of unconventional monetary easing policy in the world. Since 1999, the BOJ has implemented the zero interest rate policy (ZIRP), and it also introduced a quantitative easing policy in 2001 and announced the Stock Purchasing Plan in October 2002. In 2010-2013, after the global financial crisis and covering the Eurozone crisis period, the BOJ carried out subsequent rounds of asset purchases called "comprehensive monetary easing" policies. The BOJ went one step further by introducing quantitative and qualitative monetary easing (QQE) in April 2013 to achieve its 2\% inflation stability target, and the QQE program was further expanded in October 2014. With QQE, the BOJ started to expand the monetary base at an annual pace of 60-70 trillion yen and government bond purchases at an annual pace of 50 trillion yen, with the average remaining maturity of government bond purchases at seven years. The expansion program in October 2014 raised the annual pace of the monetary base and government bond purchases to 80 trillion yen, respectively, and extended government bond purchasing, with the average remaining maturity at 7-10 years. Since February 2016, the QQE program has also included a negative interest rate on part of banks' excess reserves with the $\mathrm{BOJ}$, and furthermore, the $\mathrm{BOJ}$ introduced yield curve control in September 2016 in order to push the inflation rate to the $2 \%$ goal. Due to the monetary easing policies over several decades in Japan, following on from Karnizova and Li [10] who compare the macroeconomic forecasting properties of the EPU, treasury yield spread and stock markets in the US, and who claim that EPU is the best predictor, outperforming the treasury spread and the stock markets, we have decided to revisit Japan's yield curve forecasting contribution to economic outlook and to further investigate how financial markets predict and adjust activities captured by economic uncertainty.

It is common to see asymmetric or nonlinear responses among financial markets when exogenous shocks occur in another assets' prices, monetary policies, price volatilities, trading information and macroeconomic variables [15,16]. Hoang et al. [17] apply a nonlinear autoregressive distributed lags (NARDL) approach to examine the effectiveness of gold as a hedge against inflation. Lacheheb and Sirag [18] also adopt this model to examine the asymmetries and nonlinear effect between oil price changes and the inflation rate. In addition, Arize et al. [19] use an asymmetric and nonlinear approach and find that when there is asymmetry between exchange rate changes and the trade balance, the depreciation effects are more significant than appreciation, while Li et al. [20] explore the asymmetric transmission of each possible determinant of credit spreads in China.

The characteristics of the NARDL model can help us to capture the short- and long-run asymmetric adjustment procedures of explained variables through both positive and negative partial sum decompositions of changes in explanatory variables. In this paper, the NARDL model helps us to investigate the relationship between the treasury yield spread and EPU in Japan and try to draw the short- and long-run asymmetric reactions of the yield spread through positive and negative partial sum decompositions of changes in EPU. Furthermore, some academic research [21,22] has provided evidence that the stock market can forecast recessions, so we speculate whether taking bond and stock markets into consideration simultaneously may describe the full picture of Japanese financial markets. 
In this study, we explore some interesting yet previously untouched questions: (1) Considering the predictive power of EPU on the macroeconomic outlook and given its backward-looking and predominantly biased information, what is the influence of negative and positive shocks in EPU on the yield spread and the forecasting actions taken by the financial market agents and the monetary policy authority in Japan? (2) Considering asset portfolios and thereby the wealth effect and asset substitution effect, when EPU suffers positive or negative shocks, what is the adjustment of the yield spreads and asset portfolios?

To sum up, this is the first paper that captures the relationships between yield spread, EPU and the stock market in Japan. Based on the NARDL method adopted, we successfully explore short- and long-run asymmetric reactions in financial variables and in treasury yield spread, which is markedly sensitive to negative shocks resulting from EPU, while taking the BOJ's Stock Purchasing Plan in October 2002 into consideration. By the features of NARDL, we discover the economic implication that flight from quality has no role in asset portfolio adjustment.

This paper is structured as follows: Section 2 describes the data and variables, Section 3 presents the analytical framework and methodology adopted, and Section 4 details our empirical results. The conclusions drawn from this study are presented in Section 5.

\section{Data and Variables}

Because the BOJ has launched the longest history of easing monetary policies since 1990s, we obtain monthly data from Bloomberg, during the period from September 1990 to October 2019, almost 30 years. The dependent variable, treasury yield spread, is defined as the difference between the on-the-run government bonds for which maturity is 10 years and two years; data on this variable were obtained from Bloomberg. The independent variable, the Japanese economic policy uncertainty (EPU) index, is based on the information obtained from leading newspapers and was constructed by Baker et al. [7].

Due to the spread's ability to forecast the economic outlook, the short-term rates determine how monetary policy is transmitted to the real economy and even the financial market, and from the investors' point of view, the difference between the short- and long-term interest rates is also the net interest income for bond holders. EPU is the representation of the economy and policy uncertainty, a source of asset price volatility and has a negative influence on the economic outlook and asset prices [23-27].

After August 1990, the BOJ reduced the official discount rate following business aggregation that occurred in February 1991 [28]. As we see from Figure 1, because of low inflation and poor economic performance that has occurred since 1990, and easing money policy, the Japanese yield spread has shown a downward trend since the Asian Financial Crisis in 1997, the period that Hasegawa and Fukuta [6] call the economic structure break. Other events occurred afterwards, namely, the dot-com bubble and Japanese Non-Performing Loans (NPL) problem in 1997, the Global Financial Crisis occurring in 2008, the Great East Japan Earthquake happening in 2011, Abenomics- the transfer of political power between the Liberal Democratic Party in 2009 and 2012, Brexit (an act of leaving by the United Kingdom from the European Union) in 2016, and Hong Kong's anti-extradition in 2019; all of the positive shocks to uncertainty helped the BOJ adopt a series of unconventional monetary policies (some events mentioned above having discussed in Hayashi and Prescott [29]).

The descriptive statistics for the variables are provided in Table 1, and the return rate of EPU is calculated by the difference of the natural logarithm of the closing prices of the near dates in the sequence of EPU.

Because of the low interest rate environment that has existed since late 1990, the treasury yield spread is less volatile than the return rate of EPU. We speculate that easing monetary policy may create considerable demand for the government, lowering the long-term yield. Besides, the rate was rarely raised, and thus, the short-term rate decreases synchronously with the long-term rate. Further, due to the demand for bonds, the standard deviation of the spread between the two rates is far below the 
standard deviation of EPU. Meanwhile, although quantitative easing causes both the two- and 10-year rates to be below zero, the spread between them never drops below zero.

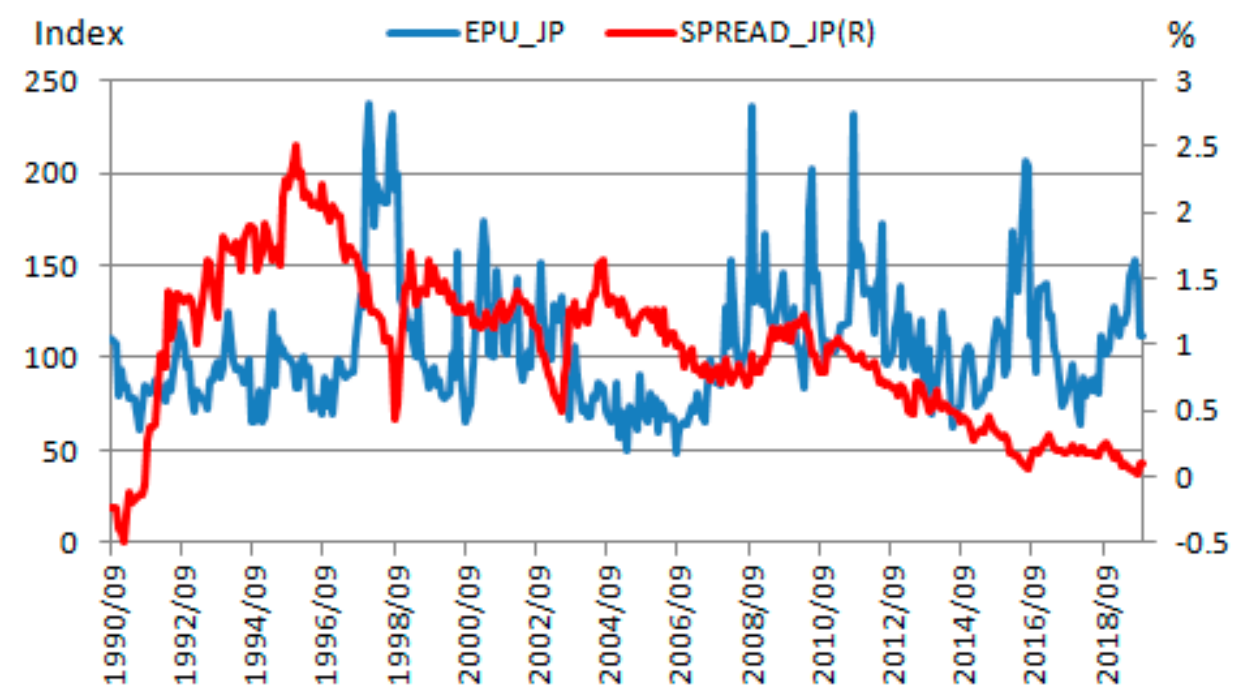

Figure 1. The row data on the Japanese treasury yield spread and Japanese EPU. Note: All data are monthly from September 1990 to October 2019 and were obtained from Bloomberg.

Table 1. Descriptive Statistics of the yield spread and return rate of EPU in Japan.

\begin{tabular}{ccc}
\hline & SPREAD & EPU \\
\hline Mean (\%) & 0.9642 & 0.0042 \\
Median (\%) & 1.0055 & -0.3876 \\
Maximum (\%) & 2.5090 & 55.7081 \\
Minimum (\%) & -0.4900 & -60.0003 \\
Std. Dev. & 0.5830 & 18.3781 \\
Skewness & 0.0208 & -0.1618 \\
Kurtosis & 2.6085 & 3.8589 \\
Jarque-Bera & 2.2812 & 12.2522 \\
p-value & 0.3241 & 0.0021 \\
\hline
\end{tabular}

Note: The $p$-value corresponds to the test of normality based on the Jarque-Bera test.

Based on the results of the Jarque-Bera test, the hypothesis of normality for the unconditional distribution for EPU is rejected; thus, it is natural to speculate that Japanese EPU does not follow normal distribution.

\section{Analytical Framework and Methodology}

In 2014, Shin et al. [30] extended the ARDL model of Pesaran and Shin [31] and Pesaran et al. [32] to NARDL, allowing for the joint analysis of both nonstationary and nonlinearity in an unrestricted error correction model that is used to draw long- and short-run asymmetries in factors that we are interested in.

In the beginning, we focus on the interaction between economic uncertainty and financial market agents, following Schorderet [33], and specify the nonlinear asymmetric long-run equation of treasury yield spread as follows:

$$
\mathrm{Y}_{\mathrm{t}}=\mathrm{L}_{\mathrm{x}}^{+} \mathrm{X}_{\mathrm{t}}^{+}+\mathrm{L}_{\mathrm{x}}^{-} \mathrm{X}_{\mathrm{t}}^{-}+\mathrm{u}_{\mathrm{t}}
$$


where $\mathrm{Y}$ denotes the yield spread, $\mathrm{X}$ is EPU's rate of returns, $\mathrm{L}_{\mathrm{x}}^{+}$and $\mathrm{L}_{\mathrm{x}}^{-}$are the parameters that describe the long-run association, $u_{t}$ is the error term, and $X_{t}^{+}$and $X_{t}^{-}$are the partial sums of the positive and negative decompositions of changes in $\mathrm{X}_{\mathrm{t}}$, respectively, formulated as follows:

$$
\begin{aligned}
& \mathrm{X}_{\mathrm{t}}^{+}=\sum_{\mathrm{i}=1}^{\mathrm{t}} \Delta \mathrm{X}_{\mathrm{i}}^{+}=\sum_{\mathrm{i}=1}^{\mathrm{t}} \max \left(\Delta \mathrm{X}_{\mathrm{i}}, 0\right) \\
& \mathrm{X}_{\mathrm{t}}^{-}=\sum_{\mathrm{i}=1}^{\mathrm{t}} \Delta \mathrm{X}_{\mathrm{i}}^{-}=\sum_{\mathrm{i}=1}^{\mathrm{t}} \min \left(\Delta \mathrm{X}_{\mathrm{i}}, 0\right)
\end{aligned}
$$

Based on the equations, the long-run relationships between the yield spread and EPU positive changes, $\mathrm{L}_{x}^{+}$, supposedly is uncertain. On the one hand, according to Hamilton and Kim [2], this relation is expected to be positive. Hamilton and Kim [2] suggest that, under uncertainty, the monetary policy authority would adopt an expansionary monetary policy, which would present higher future real economic growth. Then, based on the expectation hypothesis and investors' compensation, the expected short rates in the future will exceed the short rate currently, causing the long-term yields to rise higher than short-term yields, and the yield spread will be higher. Under this formulation, $\mathrm{L}_{\mathrm{x}}^{+}$would be positive. On the other hand, based on Veronesi [34], the aversion to state uncertainty would generate a high sensitivity of the marginal utility of consumption to news, and it would increase the demand for bonds (especially the long-term bond) from investors who are concerned about the long-term mean of their consumption. Under this mode, the yield spread would decrease, so $\mathrm{L}_{\mathrm{x}}^{+}$would be negative.

However, $\mathrm{L}_{\mathrm{x}}^{-}$represents the long-run nexus between the yield spread and EPU reduction. Based on Shin et al. [30], there exists evidence of asymmetric relationships in financial markets. When there is a good economic outlook, it would speculate that bond market agents may quickly sell their bonds (according to the expectation hypothesis, agents are quick to sell the higher-risk long-term bonds). Under this condition, $\mathrm{L}_{\mathrm{x}}^{-}$would be positive. Meanwhile, according to $\mathrm{Li}$ et al. [35], which has an uncertain influence on bond markets when there is a good macroeconomic outlook, either the investors tend to sell their bonds or increase their demand for bonds, depending on whether there is a flight from quality or no flight from quality. Under this condition, $\mathrm{L}_{\mathrm{x}}^{-}$would be uncertain.

Based on Shin et al. [30], Equation (1) can be conducted as the following asymmetric error correction model:

$$
\begin{gathered}
\Delta \mathrm{Y}_{\mathrm{t}}=\alpha_{0}+\tau \Delta \mathrm{Y}_{\mathrm{t}-1}+\theta^{+} \Delta \mathrm{X}_{\mathrm{t}-1}^{+}+\theta^{-} \Delta \mathrm{X}_{\mathrm{t}-1}^{-}+\sum_{\mathrm{i}=1}^{\mathrm{n}} \varphi_{\mathrm{i}} \Delta \mathrm{Y}_{\mathrm{t}+\mathrm{i}} \\
+\sum_{\mathrm{i}=0}^{\mathrm{m}}\left(\pi^{+} \Delta \mathrm{X}_{\mathrm{t}-\mathrm{i}}^{+}+\pi^{-} \Delta \mathrm{X}_{\mathrm{t}-\mathrm{i}}^{-}\right)+\varepsilon_{\mathrm{t}}
\end{gathered}
$$

where all variables are as defined above, $n$ and $m$ are lagged periods, $L_{x}^{+}=-\frac{\theta^{+}}{\tau}, L_{x}^{-}=-\frac{\theta^{-}}{\tau}$, these coefficients also represent the adjustment speed, and $\varepsilon_{\mathrm{t}}$ is the error term. $\sum_{\mathrm{i}=0}^{\mathrm{m}} \pi^{+}$measures the short-run influence of an EPU increase on the spread, while $\sum_{\mathrm{i}=0}^{\mathrm{m}} \pi^{-}$measures the short-run influence of an EPU reduction on the spread. Besides the asymmetric long-run relationship, the asymmetric short-run influences of EPU changes on the spread are captured.

Moreover, we use the following as the empirical implementation steps. Firstly, while the ARDL approach to cointegration is appropriate, it is necessary to adopt unit root tests to ensure that no $\mathrm{I}(2)$ variable is involved to avoid using F- statistic to test cointegration invalid. For this purpose, we apply Augmented Dickey and Fuller [36] and Phillips and Perron [37] unit root tests to examine the variables' order of integration. Secondly, we use standard OLS to estimate Equation (4). Thirdly, based on the estimated NARDL, we use the test approach of Pesaran et al. [32] and Shin et al. [30] to examine the cointegrated relationships among the variables. This approach contains the Wald F test of the null hypothesis: $\tau=\theta^{+}=\theta^{-}=0$. Finally, if cointegration exists, the examination of the long- and short-run asymmetries in the relationships between yield spread and EPU are apparent, and we draw 
the references. In this step, we can also capture the asymmetric cumulative dynamic multiplier effects of a one percent change in $\mathrm{X}_{\mathrm{t}-1}^{+}$and $\mathrm{X}_{\mathrm{t}-1}^{-}$, respectively, as: $\mathrm{m}_{\mathrm{s}}^{+}=\sum_{\mathrm{j}=0}^{\mathrm{s}} \frac{\partial \mathrm{Y}_{\mathrm{t}+\mathrm{j}}}{\partial \mathrm{X}_{\mathrm{t}-1}^{+}} ; \mathrm{m}_{\mathrm{s}}^{-}=\sum_{\mathrm{j}=0}^{\mathrm{s}} \frac{\partial \mathrm{Y}_{\mathrm{t}+\mathrm{j}}}{\partial \mathrm{X}_{\mathrm{t}-1}^{-}} ; \mathrm{s}=0,1$, $2, \ldots$ Note that as $\mathrm{s} \rightarrow \infty, \mathrm{m}_{\mathrm{s}}^{+} \rightarrow \mathrm{L}_{\mathrm{x}}^{+}$and $\mathrm{m}_{\mathrm{s}}^{-} \rightarrow \mathrm{L}_{\mathrm{x}}^{-}$.

Next, we depict the empirical results, including unit tests, eliminating the existing of I(2) series, and dynamic symmetric and asymmetric estimation of yield spread adjustments, following the NARDL method.

\section{Empirical Results}

\subsection{Unit Tests}

To make sure that no I(2) variables exist, firstly we test unit root tests without examining for the stationary of the variables. From our output statistics shown in Table 2, both ADF and PP show that the Japanese yield spread and EPU's rate of return are both stationary and I(0) time series. Since the unit root tests results suggest that none of the variables are I(2), we further test the asymmetric long-run relations among the variables.

Table 2. Unit Root Tests of the yield spread and EPU rate of return in Japan.

\begin{tabular}{|c|c|c|c|c|}
\hline & \multicolumn{2}{|c|}{ ADF } & \multicolumn{2}{|c|}{ PP } \\
\hline & Level & 1st Difference & Level & 1st Difference \\
\hline SPREAD & $0.0010 * * *$ & $0.000 * * *$ & $0.0138^{* *}$ & $0.0000^{* * *}$ \\
\hline EPU & $0.0016^{* * *}$ & $0.000^{* * *}$ & $0.0000^{* * *}$ & $0.0001^{* * *}$ \\
\hline
\end{tabular}

\subsection{Dynamic Symmetric and Asymmetric Estimation of SPREAD Adjustments}

We proceed to investigate whether the variables adopted in our research are cointegrated.

The NARDL regression of the samples are provided in Table 3. We test the joint null hypothesis of no cointegration $\mathrm{F}_{\mathrm{pss}}: \tau=\theta^{+}=\theta^{-}=0$ in Equation (4). The results significantly show that there exist long-run equilibrium relationships between the spread and EPU. We explore that among the four models, the $\mathrm{F}_{\mathrm{pss}}$ statistics are all significant at the $10 \%$ level, and the optimal lag length is two.

Table 3. Dynamic symmetric and asymmetric estimations of SPREAD adjustments.

\begin{tabular}{|c|c|c|c|c|c|c|c|}
\hline \multirow[b]{2}{*}{$\mathrm{L}_{\mathrm{x}}$} & \multicolumn{2}{|c|}{ Lr/SrSymmetric } & \multirow{2}{*}{$\begin{array}{c}\begin{array}{c}\text { Lr Symmetric } \\
\text { /Sr }\end{array} \\
\text { Asymmmetric } \\
1.2917\end{array}$} & \multicolumn{3}{|c|}{$\begin{array}{c}\text { Lr } \\
\text { Asymmetric } \\
\text { /Sr Symmetric }\end{array}$} & \multirow{2}{*}{$\begin{array}{c}\begin{array}{c}\mathbf{L r} / \mathbf{S r} \\
\text { Asymmetric }\end{array} \\
0.3104 \\
0.1486\end{array}$} \\
\hline & 1.2755 & $\mathrm{~L}_{\mathrm{x}}$ & & $\begin{array}{l}\mathrm{L}_{X}^{+} \\
\mathrm{L}_{\bar{x}}^{-}\end{array}$ & $\begin{array}{l}0.2449 \\
0.3261\end{array}$ & $\begin{array}{l}\mathrm{L}_{x}^{+} \\
\mathrm{L}_{x}^{-}\end{array}$ & \\
\hline Adj. $R^{2}$ & 0.0445 & Adj. $R^{2}$ & 0.0419 & Adj. $R^{2}$ & 0.0908 & Adj. $R^{2}$ & 0.0862 \\
\hline AIC & -1.4121 & AIC & -1.4094 & AIC & -1.4561 & AIC & -1.4511 \\
\hline LM & 1.5191 & LM & 1.4815 & LM & 2.2724 & LM & 2.1349 \\
\hline $\mathrm{F}_{\mathrm{pss}}$ & $2.5307^{*}$ & $\mathrm{~F}_{\mathrm{pss}}$ & 2.6493 * & $\mathrm{F}_{\mathrm{pss}}$ & $7.7239 * * *$ & $\mathrm{~F}_{\mathrm{pss}}$ & $7.5233 * * *$ \\
\hline $\mathrm{W}_{\mathrm{LR}}$ & & $\mathrm{W}_{\mathrm{LR}}$ & 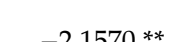 & $\mathrm{W}_{\mathrm{LR}}$ & 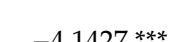 & $\mathrm{W}_{\mathrm{LR}}$ & $-4.0379 * * *$ \\
\hline$W_{S R}$ & & $W_{S R}$ & $-2.15 \%$ & $W_{S R}$ & - & $W_{S R}$ & $-2.3297 * *$ \\
\hline
\end{tabular}

Notes: $1 . L_{x}^{+}$and $L_{x}^{-}$represent the long-run coefficients, where $L_{x}^{+}=-\frac{\theta^{+}}{\tau}, L_{x}^{-}=-\frac{\theta^{-}}{\tau} . F_{p s s}$ is the modified $F$ statistic for the null of $\tau=\theta^{+}=\theta^{-}=0$, as in Pesaran al. [32] and Shin et al. [30]. 2. The $p$-values can be estimated using the Wald test statistics of a bootstrap for the significance levels of $1 \%, 5 \%$ and $10 \% .3 . \mathrm{W}_{\mathrm{LR}}$ and $\mathrm{W}_{\mathrm{SR}}$ denote the Wald test statistics for the long- and short-run symmetries, respectively, and ******* represent significant statistics at the level of $10 \%, 5 \%$ and $1 \%$, respectively.

Because of the revealing of long-run cointegration relationships between the yield spread and EPU, we specifically examine the results of long- or short-run asymmetric characteristics from Equation (4) with the Wald tests for both the long- $\left(\mathrm{W}_{\mathrm{LR}}\right)$ and short-run $\left(\mathrm{W}_{\mathrm{SR}}\right)$. According to the lowest AIC, 
among the four models, model 3 (AIC $=-1.4561$ ), where the long-run asymmetric and the short-run symmetric have the best fit, and using the Wald test at a $10 \%$ significance level, the estimated results clearly confirm the long-run coefficients of yield spread. When we examine the asymmetric effect in the long run, the result of the Wald test applied to explore the positive shock in EPU has a significant coefficient of 0.2449 , and the negative shock in EPU has a significant coefficient of 0.3261 . That means, in the long run, the role of a negative shock in EPU dominates the positive shock, and a negative shock in economic policy uncertainty has a significant and asymmetric effect on the yield spread. As we see from Figure 2, the Japanese EPU decrease is significant in the long run, and the dynamic multiplier of the EPU decrease on the yield spread, while in the short run, the amplitude of the response of the negative changes in EPU and negative changes in EPU are the same. The results are in line with the investigation from Shin et al. [30] that when the uncertainty decreases, indicating a good economic outlook, according to the expectation hypothesis, bond market agents tend to change their strategies much more quickly to sell higher-risk long-term bonds.

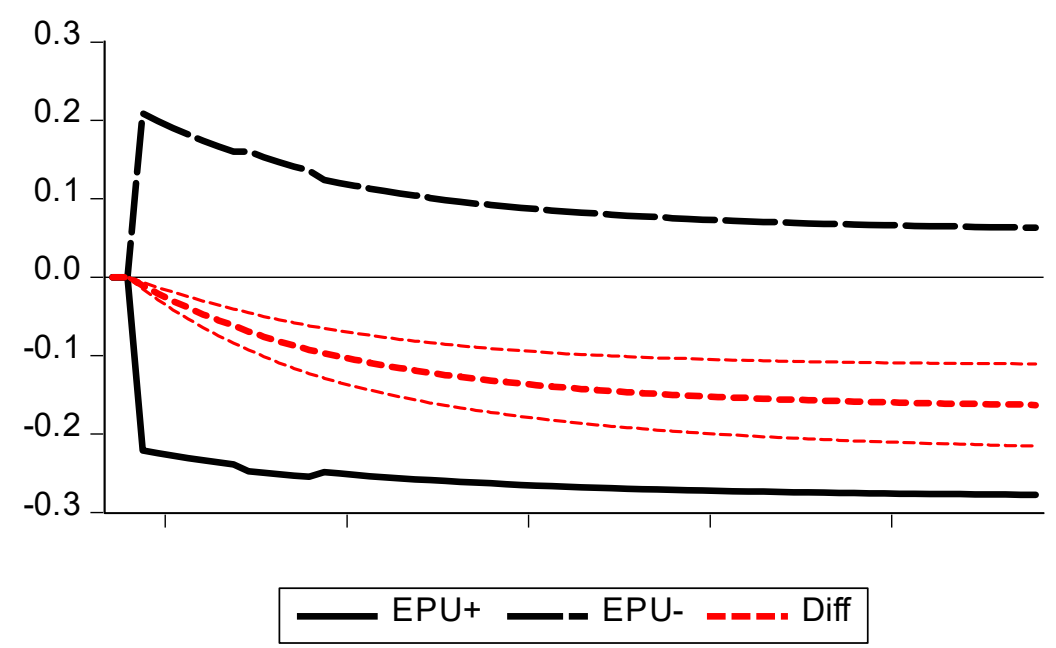

Figure 2. SPREAD dynamic multipliers in Lr Asymmetric/Sr Symmetric.

In conclusion, the low interest environment, especially after the Asia Financial Crisis occurred in 1997, lasted for almost 30 years and causes Japanese financial market agents and the BOJ to be sensitive to a good outlook for performance in Japan and adjust asset allocation and monetary policy forecasting as a response. However, when we go back to check the coefficient of $\mathrm{L}_{X}^{+}$, meaning the negative macroeconomic outlook in Japan, the significant positive coefficient of $\mathrm{L}_{\mathrm{X}}^{+}$is in line with Hamilton and Kim [2] and reveals that when Japan suffers from an uncertain economic outlook, expansionary monetary policy would cause the yield of long-term bonds to increase more than that of short-term yields and the yield spread to increase. This is ambiguous because, according to Figure 1 and past Japanese monetary policy, the BOJ simultaneously adopted unconventional monetary policy and announced the Stock Purchasing Plan in October 2002. We speculate that this policy has greatly increased the demand not only for bonds but also stocks for several decades. This economic implication is not in line with Hamilton and Kim [2], and merely examining the nexus between the yield spread and EPU could not capture the full picture of the low interest rate environment in Japan.

We now have the motivation to take the influence of the stock market on the yield spread into consideration.

\subsection{Dynamic Symmetric and Asymmetric Estimation of SPREAD Adjustments with EPU and Stock Market}

Accompanying with quality and quantitative easing, the BOJ announced the Stock Purchasing Plan in October 2002. Similar to EPU and the treasury yield spread, stock markets are used to forecast the macroeconomy. We take portfolio management into consideration and adopt stock markets as the 
control variable. Connolly et al. [38] speculate that, due to asset substitution effects, the positive shocks in EPU have a flight-to-quality effect, and investors tend to sell off more risky stock and buy safer bonds, leading to a negative effect in the stock-bond correlations. While the negative shocks in EPU may have a flight-from-quality effect, investors tend to sell off safer bonds and buy risker stocks, also leading to a negative effect in stock-bond correlations. The above discussion follows Li et al. [35], but Li et al. [35] provide more comment than Connolly et al. [38] on the negative shock occurring on EPU. Li et al. [35] reveal that when the economic outlook improves, there may be no flight from quality, which increases investors' demand for both stocks and bonds, thereby tightening stock-bond correlations.

We adopt the Nikkei 225 index as the proxy of Stock Purchasing Plan because Nikkei 225 has the longest launching history, and is the representative of the stock market in Japan. As seen in Tables 1 and 4, the rate of return of the Nikki 225 is less volatile than economic policy uncertainty, and due to the long-run easing of monetary policy and high demand for treasury, the yield spread is the most stable. The Jarque-Bera test results shown in Table 4 reveal that the Nikkei 225 rate of return does not follow normal distribution. As shown in Figure 3, since the Asia Financial Crisis in 1997, the BOJ's long-term expanding monetary policy has caused the yield spread decreasing afterwards. Meanwhile, unconventional monetary policy has supported Japanese stock markets for several decades.

Table 4. Descriptive Statistics of the rate of return of the Nikkei 225.

\begin{tabular}{|c|c|c|c|c|c|c|c|c|}
\hline $\begin{array}{c}\text { Mean } \\
(\%)\end{array}$ & $\begin{array}{l}\text { Medium } \\
(\%)\end{array}$ & $\begin{array}{c}\text { Maximum } \\
(\%)\end{array}$ & $\begin{array}{c}\text { Minimum } \\
(\%)\end{array}$ & $\begin{array}{l}\text { Std. } \\
\text { Dev. }\end{array}$ & Skewness & Kurtosis & Jarque-Bera & $p$-Value \\
\hline 0.0253 & 0.4188 & 18.2873 & -27.2162 & 5.9383 & -0.4460 & 3.9537 & 24.8013 & 0.0000 \\
\hline
\end{tabular}

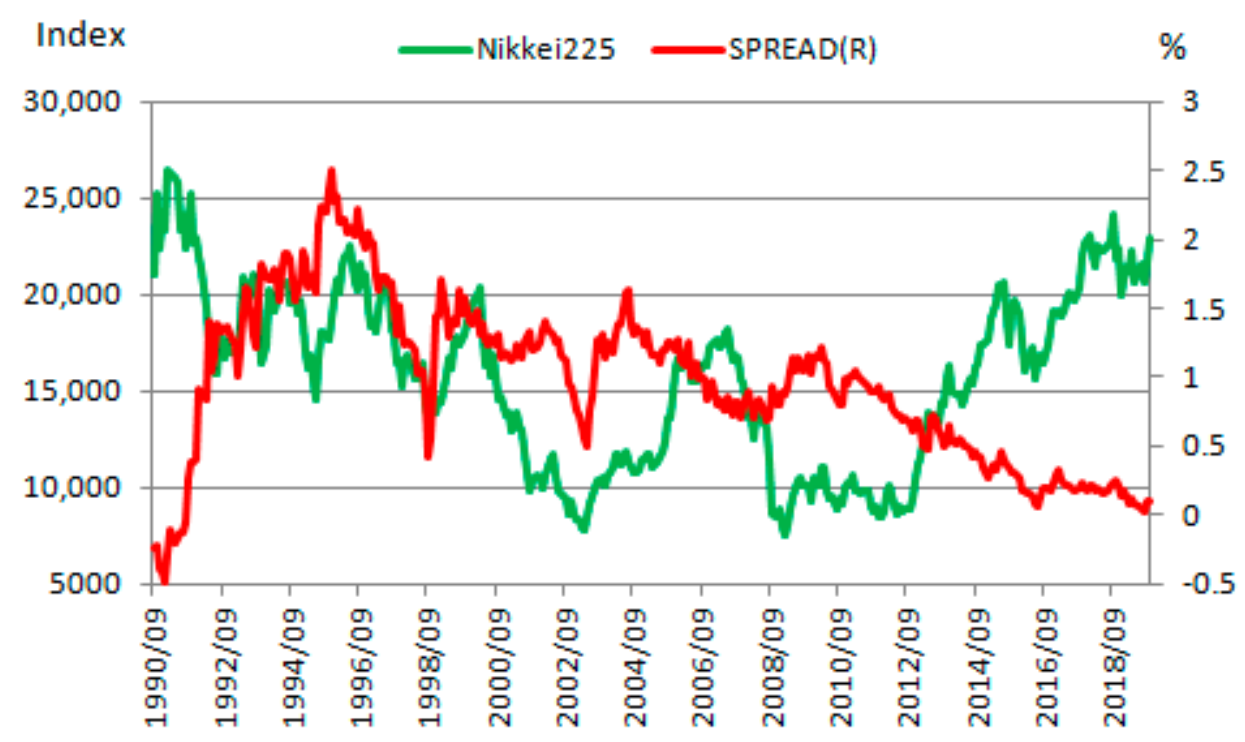

Figure 3. The row data on the Japanese treasury yield spread and Nikkei 225. Note: All data are monthly from September 1990 to October 2019 and were obtained from Bloomberg.

According to the unit roots of the Nikkei 225's rate of return shown in Table 5, both the ADF and PP show that the Nikkei 225 rate of return is I(1) series. Since the unit root test result proves that none of the variables in Tables 2 and 5 are I(2), we proceed to test where there exists the asymmetric long-run relation among the variables. 
Table 5. Unit Root tests of the Nikkei 225 rate of return.

\begin{tabular}{ccccc}
\hline \multicolumn{4}{c}{ ADF } & PP \\
\hline & Level & 1st Difference & Level & 1st Difference \\
\hline Nikkei 225 & 0.5390 & $0.0000^{* * *}$ & 0.5406 & $0.0000^{* * *}$ \\
\hline \multicolumn{5}{c}{ Note: ${ }^{* * *}$ denote significance at $1 \%}$.
\end{tabular}

We establish the following asymmetric long-run equation for the yield spread including EPU and the stock market as explanatory variables:

$$
\mathrm{Y}_{\mathrm{t}}=\mathrm{L}_{\mathrm{x}}^{+} \mathrm{X}_{\mathrm{t}}^{+}+\mathrm{L}_{\mathrm{x}}^{-} \mathrm{X}_{\mathrm{t}}^{-}+\mathrm{L}_{\mathrm{z}}^{+} \mathrm{Z}_{\mathrm{t}}^{+}+\mathrm{L}_{\mathrm{z}}^{-} \mathrm{Z}_{\mathrm{t}}^{-}+\mathrm{u}_{\mathrm{t}}^{\prime}
$$

where $\mathrm{Y}$ is the treasury spread, $\mathrm{X}$ is the rate of return of the EPU, and $\mathrm{Z}$ denotes the rate of return of the Nikkei 225. In Equation (5), $X_{t}^{+}$and $X_{t}^{-}$denote the respective partial sums of the positive and negative changes in the rate of return of the EPU, and $Z_{t}^{+}$and $Z_{t}^{-}$represent the partial sums of the positive and negative changes in the rate of return of the Nikkei 225, respectively. The independent variables are decomposed into their negative and positive partial sums for decreasing and increasing as follows:

$$
\begin{aligned}
& \mathrm{x}_{\mathrm{t}}^{+}=\sum_{\mathrm{i}=1}^{\mathrm{t}} \Delta \mathrm{x}_{\mathrm{i}}^{+}=\sum_{\mathrm{i}=1}^{\mathrm{t}} \max \left(\Delta \mathrm{x}_{\mathrm{i}}^{+}, 0\right) \\
& \mathrm{x}_{\mathrm{t}}^{-}=\sum_{\mathrm{i}=1}^{\mathrm{t}} \Delta \mathrm{x}_{\mathrm{i}}^{-}=\sum_{\mathrm{i}=1}^{\mathrm{t}} \max \left(\Delta \mathrm{x}_{\mathrm{i}}^{-}, 0\right)
\end{aligned}
$$

where $x_{t}$ represents $X_{t}$ and $Z_{t}$.

Based on Equation (5) and Connolly et al. [38], the asset substitution effects cause both $\mathrm{L}_{\mathrm{x}}^{+}$and $\mathrm{L}_{\mathrm{z}}^{-}$to be negative when there are positive shocks in EPU (meaning that the positive shocks occurring in EPU would lead to a negative nexus between stocks and bonds). However, negative shocks in the EPU may have flight-from-quality effects, also leading to a negative effect on stock-bond correlations, and both $\mathrm{L}_{\mathrm{x}}^{-}$and $\mathrm{L}_{\mathrm{z}}^{+}$are positive. Li et al. [35] provide more comments than Connolly et al. [38] on the negative shock occurring in the EPU. Li et al. [35] claim that when the economic outlook improves, investors may increase their demand for both stocks and bonds, thereby pushing up stock-bond correlations. In this mode, both $\mathrm{L}_{\mathrm{x}}^{-}$and $\mathrm{L}_{\mathrm{z}}^{+}$would be negative. Thus, we speculate from Shin et al. [30] revealing the characteristics of financial markets' rigidity, quick to selling and slow to buying, which reflects asymmetric long-run shocks on the EPU and stock market and passes through to the yield spread.

Based on Shin et al. [30], Equation (5) can be conducted as the following asymmetric error correction model:

$$
\begin{aligned}
\Delta \mathrm{Y}_{\mathrm{t}}= & \alpha_{0}+\tau \Delta \mathrm{Y}_{\mathrm{t}-1}+\theta^{+} \Delta \mathrm{X}_{\mathrm{t}-1}^{+}+\theta^{-} \mathrm{X}_{\mathrm{t}-1}^{-}+\beta \Delta \mathrm{Z}_{\mathrm{t}-1}^{+}+\gamma \Delta \mathrm{Z}_{\mathrm{t}-1}^{-} \\
& +\sum_{\mathrm{i}=1}^{\mathrm{n}} \varphi_{\mathrm{i}} \Delta \mathrm{Y}_{\mathrm{t}-\mathrm{i}}+\sum_{\mathrm{i}=0}^{\mathrm{m}}\left(\pi^{+} \Delta \mathrm{X}_{\mathrm{t}-\mathrm{i}}^{+}+\pi^{-} \Delta \mathrm{X}_{\mathrm{t}-\mathrm{i}}^{-}\right) \\
& +\sum_{\mathrm{i}=0}^{\mathrm{r}}\left(\omega^{+} \Delta \mathrm{Y}_{\mathrm{t}-\mathrm{i}}^{+}+\omega^{-} \Delta \mathrm{Y}_{\mathrm{t}-\mathrm{i}}^{-}\right)+\varepsilon_{\mathrm{t}}^{\prime}
\end{aligned}
$$

where $n, m$ and $r$ are lag orders and we seek to examine $L_{x}^{+}=-\frac{\theta^{+}}{\tau}, L_{x}^{-}=-\frac{\theta^{-}}{\tau}, L_{z}^{+}=-\frac{\beta}{\tau}$, and $L_{z}^{-}=-\frac{\gamma}{\tau}$. These coefficients represent the adjustment speed. $\sum_{\mathrm{i}=0}^{\mathrm{m}} \pi^{+}$and $\sum_{\mathrm{i}=0}^{\mathrm{r}} \omega^{+}$are the short-run influences of an increase in Japanese EPU and the Nikki 225 on the yield spread, respectively, while $\sum_{\mathrm{i}=0}^{\mathrm{m}} \pi^{-}$ and $\sum_{\mathrm{i}=0}^{\mathrm{r}} \omega^{-}$are the short-run influences of EPU and the stock market reduction, respectively, on the spread. In the first step, the null hypothesis of a modified $F$ test is that no cointegration $\left(\tau=\theta^{+}=\theta^{-}=\beta=\gamma=0\right)$ is tested against the alternative of cointegration for Equation (8). Next, the standard Wald test is used to examine the short-run symmetry $\left(\Pi=\pi^{+}=\pi^{-}=\omega^{+}=\omega^{-}\right)$and 
long-run symmetry ( $\left.\Phi=\theta^{+}=\theta^{-}=\beta=\gamma\right)$ for all variables. Finally, the asymmetry Equation (8) is used to estimate the symmetric cumulative dynamic multiplier effects:

$$
\begin{aligned}
& \mathrm{m}_{\mathrm{S} 1}^{+}=\sum_{\mathrm{j}=0}^{\mathrm{s}} \frac{\partial \mathrm{Y}_{\mathrm{t}+\mathrm{j}}}{\partial \mathrm{X}_{\mathrm{t}-1}^{+}} ; \mathrm{m}_{\mathrm{S} 1}^{-}=\sum_{\mathrm{j}=0}^{\mathrm{s}} \frac{\partial \mathrm{Y}_{\mathrm{t}+\mathrm{j}}}{\partial \mathrm{X}_{\mathrm{t}-1}^{-}} ; \mathrm{m}_{\mathrm{S} 2}^{+}=\sum_{\mathrm{j}=0}^{\mathrm{s}} \frac{\partial \mathrm{Y}_{\mathrm{t}+\mathrm{j}}^{+}}{\partial \mathrm{Z}_{\mathrm{t}-1}^{+}} ; \mathrm{m}_{\mathrm{S} 2}^{-}=\sum_{\mathrm{j}=0}^{\mathrm{s}} \frac{\partial \mathrm{Y}_{\mathrm{t}+\mathrm{j}}}{\partial \mathrm{Z}_{\mathrm{t}-1}^{-}}, \mathrm{s}=0,1,2, \ldots \\
& \quad \text { Notethatass } \rightarrow \infty, \mathrm{m}_{\mathrm{S} 1}^{+} \rightarrow \mathrm{L}_{\mathrm{x}}^{+}, \mathrm{m}_{\mathrm{S} 1}^{-} \rightarrow \mathrm{L}_{\mathrm{x}}^{-}, \mathrm{m}_{\mathrm{S} 2}^{+} \rightarrow \mathrm{Z}_{\mathrm{x}}^{+}, \text {and } \mathrm{m}_{\mathrm{S} 2}^{-} \rightarrow \mathrm{Z}_{\mathrm{x}}^{-} .
\end{aligned}
$$

As shown in the NARDL regression in Table 6, the results reveal statistically significant evidence $\mathrm{F}_{\mathrm{pss}}: \tau=\theta^{+}=\theta^{-}=\beta=\gamma=0$ of long-run cointegration relations among the yield spread, EPU and stock market in Japan. We can observe that among the four models, the $\mathrm{F}_{\mathrm{pss}}$ statistics are all significant at the $10 \%$ level, and the optimal lag length is two.

Table 6. Dynamic symmetric and asymmetric estimations of SPREAD adjustments with EPU and

\begin{tabular}{|c|c|c|c|c|c|c|c|}
\hline & \multicolumn{2}{|c|}{ Lr/SrSymmetric } & \multicolumn{2}{|l|}{$\begin{array}{l}\text { Lr Symmetric } \\
\text { /Sr } \\
\text { Asymmmetric }\end{array}$} & \multicolumn{2}{|l|}{$\begin{array}{c}\mathrm{Lr} \\
\text { Asymmetric } \\
\text { /Sr Symmetric }\end{array}$} & \multirow[t]{2}{*}{$\begin{array}{c}\mathrm{Lr} / \mathrm{Sr} \\
\text { Asymmetric }\end{array}$} \\
\hline & & $\mathrm{L}_{x}^{+}$ & 0.4927 & & & $\mathrm{~L}_{\mathrm{X}}^{+}$ & \\
\hline $\mathrm{L}_{\mathrm{x}}$ & 1.0054 & $\mathrm{~L}_{\bar{x}}^{\lambda}$ & -0.5784 & $\mathrm{~L}_{\mathrm{x}}$ & 0.5176 & $\mathrm{~L}_{\bar{x}}^{\lambda}$ & -0.5328 \\
\hline$\hat{\mathrm{L}_{\mathrm{Z}}}$ & 0.1203 & $\begin{array}{l}\mathrm{L}_{\mathrm{Z}}^{+} \\
\mathrm{L}_{\mathrm{Z}}^{-}\end{array}$ & $\begin{array}{c}-2.5273 \\
0.5230\end{array}$ & $\hat{\mathrm{L}_{\mathrm{Z}}}$ & 0.1925 & $\mathrm{~L}_{\mathrm{Z}}^{\hat{+}}$ & $\begin{array}{c}-1.8436 \\
0.6720\end{array}$ \\
\hline Adj. $R^{2}$ & 0.1913 & Adj. $R^{2}$ & 0.2316 & Adj. $R^{2}$ & 0.2238 & Adj. $R^{2}$ & 0.2674 \\
\hline AIC & 1.0429 & AIC & 0.9945 & AIC & 1.0018 & AIC & 0.9494 \\
\hline LM & 0.6049 & LM & 1.6333 & LM & 0.6133 & LM & 1.5123 \\
\hline $\mathrm{F}_{\mathrm{pss}}$ & $18.2088^{* * *}$ & $\mathrm{~F}_{\mathrm{pss}}$ & $15.7375^{* * *}$ & $\mathrm{~F}_{\mathrm{pss}}$ & $16.6151^{* * *}$ & $F_{p s s}$ & $15.0487^{* * *}$ \\
\hline $\mathrm{W}_{\mathrm{LR}}$ & & $\mathrm{W}_{\mathrm{LR}}$ & & $\mathrm{W}_{\mathrm{LR}}$ & & $\mathrm{W}_{\mathrm{LR}}$ & $11.2135^{* * *}$ \\
\hline$W_{S R}$ & & $W_{S R}$ & $2.7386^{*}$ & $W_{S R}$ & $3.0943^{* *}$ & $W_{\mathrm{SR}}$ & -0.9289 \\
\hline
\end{tabular}
stock market.

Notes: $1 . \mathrm{L}_{\mathrm{x}}^{+}, \mathrm{L}_{\mathrm{x}}^{-}, \mathrm{L}_{\mathrm{z}}^{+}$, and $\mathrm{L}_{\mathrm{z}}^{-}$are the long-run coefficients, where $\mathrm{L}_{\mathrm{x}}^{+}=-\frac{\theta^{+}}{\tau}, \mathrm{L}_{\mathrm{x}}^{-}=-\frac{\theta^{-}}{\tau}, \mathrm{L}_{\mathrm{z}}^{+}=-\frac{\beta}{\tau}$, and $\mathrm{L}_{\mathrm{z}}^{-}=-\frac{\gamma}{\tau}$. $\mathrm{F}_{\text {pass }}$ are the modified $\mathrm{F}$ statistics for the null of $\tau=\theta^{+}=\theta^{-}=\beta=\gamma=0$ proposed by Pesaran et al. [32] and Shin et al. [30]. 2. The $p$-values can be estimated using the Wald test statistics of a bootstrap for the significance levels of $10 \%, 5 \%$ and $1 \% .3 . \mathrm{W}_{\mathrm{LR}}$ and $\mathrm{W}_{\mathrm{SR}}$ denote the Wald test statistics for the long- and short-run symmetries, respectively, and $* * *$, and $* *$ are statistically significant statistics at the level of $10 \%, 5 \%$ and $1 \%$, respectively.

Because a long-run equilibrium nexus exists among the three variables, we specifically examine the results where long- or short-run asymmetric characteristics exist from Equation (8) adopting the Wald tests for both the long- $\left(\mathrm{W}_{\mathrm{LR}}\right)$ and short-run $\left(\mathrm{W}_{\mathrm{SR}}\right)$. The result of the dynamic multipliers is presented in Table 6. Looking at the lowest AIC of the four models, model 4 (AIC $=0.9494$ ), where the long and short runs are both asymmetric, is the model with the best fit, and using the Wald test at a $10 \%$ significance level, the estimated results clearly confirm the coefficients of the spread. Additionally, from Figure 4, we confirm the existence of overall asymmetry between treasury yield spread and EPU. Furthermore, as seen from Figure 4, the Japanese EPU decrease is significant in the whole sample period. Therefore, we will now look at the dynamic multiplier of the EPU decrease on the yield spread.

When we examine the asymmetric effect, the result of the Wald test applied to affirm the positive shock in EPU has a significant coefficient and a value of 0.3858 . The negative shock in EPU has a significant coefficient of -0.5328 , the positive shock in the Nikkei 225 has a significant coefficient of -1.8436 , and the negative shock in the Nikkei 225 has a significant coefficient of 0.6720 . We find that the amplitude of the negative shock in EPU dominates the positive shock, and the positive shock in the Nikki 225 dominates the negative shock. The influence of good economic performance on the yield spread in our sample is in line with Li et al. [35], indicating that the long-term easing monetary policy increases demand both on bonds (especially the long-term treasury, according to the expectation hypothesis) and stock markets without flight from quality.

Furthermore, when we take the stock market as a control variable, both the coefficients of the positive and negative shocks of the EPU are larger than those coefficients without taking the stock market into consideration. We speculate that when uncertainty decreases or the stock market is outperformed, meaning that there is a good economic outlook, bond market agents and monetary policy authorities tend to change their strategies much more than when there is a poor economic 
outlook. This result confirms that while we consider the bond-stock correlation, when there is a negative shock in economic policy uncertainty or a positive shock in stock market, both have significant effects on the yield spread.

In conclusion, intending to expand inflation and the economy, the monetary authority used to ease money policy and, while coming to the better macroeconomy, namely due to out-of-expectation shocks, it has had a larger influence on the financial market in Japan.

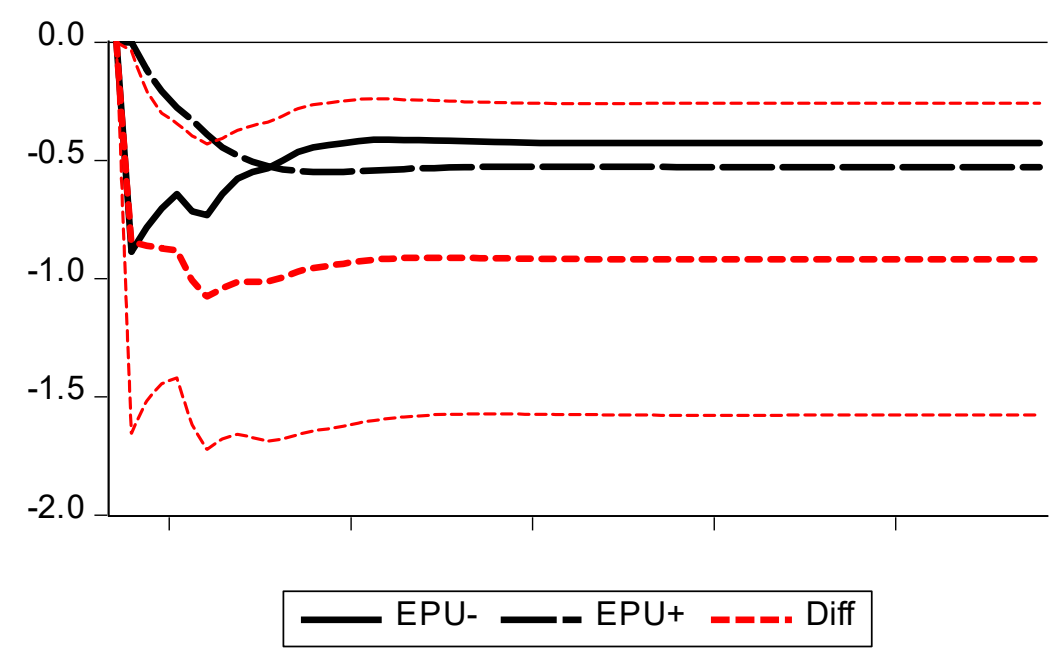

Figure 4. SPREAD dynamic multipliers in Lr Asymmetric/Sr Asymmetric with the Nikkei 225 as the control variable.

As the term premium between long- and short-term interest rates' existing time variation, recently, some academic shows that the forecasting contribution of the yield spread is shrinking. Further, because of the longest unconventional monetary policies adapted in the world, the mixed results and even failure of yield spread about macroeconomic outlook forecasting contribution in Japan. Recently, research has identified EPU as an indicator of macroeconomic outlook forecasting tool. Due to quality and quantitative easing, the BOJ announced the Stock Purchasing Plan in October 2002, and the scripture has explored that stock markets can foresee the economic outlook. Accordingly, we have the motivation to examine the relationship among yield spread, EPU and stock market.

There exist asymmetric or nonlinear responses in financial markets when exogenous shocks occur in other assets' prices. The NARDL model that we adopt in this paper helps us to we find a significant positive nexus between the treasury yield spread and EPU reduction in the long run. This means when facing a good economy, bond agents are quick to sell, especially higher-risk long-term interest rate bonds, whereas take BOJ's Stock Purchasing Plan in October 2002 into consideration, by the features of NARDL, we have the economic implication that the role of flight from quality does not exist in the asset portfolio adjustment.

\section{Concluding Remarks and Implications}

Japan is the country that adopted the longest history of unconventional monetary policies in the world. Since 1990s, the BOJ started to employ easing monetary to rescue Japanese low inflation and poor economic performance, including ZIRP, quantitative easing, qualitative and quantitative easing, and also assets purchasing, such as Stock Purchasing Plan in 2002 and Yield Curve Control in 2016). People traditionally rely on yields spreads as indicators for forecasting probability of a recession, whereas Hasegawa and Fukuta [6] reveal that because of the economic structure break in 1996, the Japanese spread lost some of its forecasting ability. Besides, the time variation existing in the adjustment of the term premium appeared in the long- and short-term interests also decline the contribution of prediction. Based the particularity of Japanese monetary policy and the declining 
recession predictive ability, we have the motivation to examine the reactions among treasury yield spread and other financial variables.

To our best knowledge, this is the first paper that explores the response of Japanese treasury yield spread which may have asymmetric and nonlinear features when exogenous variables occur shocks. We use a proper NARDL methodology to successfully capture the short- and long-run asymmetric reactions in treasury yield spread, which is markedly sensitive to negative shocks resulting from EPU, the indicator identified as the predicting macroeconomic outlook index. In addition, we explore that, in Japan, in the long run, the role of a negative shock in EPU dominates the positive shock, and a negative shock in economic policy uncertainty has a significant and asymmetric effect on the yield spread. The results are in line with the investigation from Shin et al. [30] that when the uncertainty decreases, indicating a good economic outlook, according to the expectation hypothesis, bond market agents tend to change their strategies much more quickly to sell higher-risk long-term bonds. However, when we go back to check the influence of positive shock in EPU on yield spread, we have ambiguous empirical results. We speculate that merely examining the nexus between the yield spread and EPU could not capture the full picture of the low interest rate environment in Japan.

Next, due to the power of stock markets to forecast the macroeconomy, and the BOJ announced the Stock Purchase Plan as one of the quantitative easing tools that have been employed since October 2002. Taking the Japanese stock market into consideration (here we take Nikkei 225 as the proxy of Stock Purchasing Plan), based on portfolio management, we find that the amplitude of a negative shock in EPU dominates its positive shock, and the positive shock in the Nikkei 225 dominates its negative shock. The influence of good economic performance on the yield spread in our sample is in line with Li et al. [35]: long-term easing monetary policy increases demand for both bonds (especially the demand for the long-term treasuries, according to the expectation and compensation hypothesis) and stocks, and the hypothesis of flight to (or from) quality is not supported.

In conclusion, intending to expand inflation and the economy, the monetary policy authority in Japan has been used to easing money policy for several decades. When we take the stock market into consideration, and the correlations among the yield spread, EPU and stock market, we capture the full picture of the effects of the low interest rate environment in Japan, while long-term unconventional monetary policy causes demand for boths and stocks. Although it contributes by highlighting and investigating the significance of the policy implementations, this study could possibly be extended to all European Union countries, the United States, and emerging markets or by applying a regional comparison.

Author Contributions: Conceptualization, M.-C.W. and P.-L.K.; methodology, T.C.; software, T.C.; validation, C.-L.C. and C.-S.C.; formal analysis, M.-C.W. and P.-L.K.; investigation, C.-S.C.; resources, C.-S.C.; data curation, P.-L.K.; writing — original draft preparation, P.-L.K.; writing - review and editing, C.-S.C. and C.-L.C.; visualization, P.-L.K.; supervision, C.-L.C. and T.C.; project administration, C.-S.C.; funding acquisition, M.-C.W. and P.-L.K. All authors have read and agreed to the published version of the manuscript.

Funding: This research received no external funding.

Conflicts of Interest: The authors declare no conflict of interest.

\section{References}

1. Estrella, A.; Rodrigues, A.R.; Schich, S. How stable is the predictive power of the yield curve? Evidence from Germany and the United States. Rev. Econ. Stat. 2003, 85, 629-644. [CrossRef]

2. Hamilton, J.; Kim, D. A re-examination of the predictability of the yield spread for real economic activity. J. Money Credit Bank. 2002, 34, 340-360. [CrossRef]

3. Erdogan, O.; Bennett, P.; Ozyildirim, C. Recession prediction using yield curve and stock market liquidity deviation measures. Rev. Financ. 2015, 19, 407-422. [CrossRef]

4. Chinn, M.; Kucko, K. The predictive power of the yield curve across countries and time. Int. Financ. 2015, 18, 129-156. [CrossRef] 
5. Hirata, H.; Ueda, K. The Yield Spread as a Predictor of Japanese Recessions; Bank of Japan Working Paper Series Research and Statistics D; Bank of Japan: Tokyo, Japan, 1998.

6. Hasegawa, M.; Fukuta, Y. An empirical analysis of information in the yield spread on future recessions in Japan. Appl. Econ. 2011, 43, 1865-1881. [CrossRef]

7. Baker, S.R.; Bloom, N.; Davis, S.J. Measuring Economic Policy Uncertainty. Q. J. Econ. 2016, 131, $1593-1636$. [CrossRef]

8. Born, B.; Breuer, S.; Elstner, S. Uncertainty and the Great Recession. Oxf. Bull. Econ. Stat. 2017, 70, 951-971. [CrossRef]

9. Born, B.; Pfeifer, J. Policy risk and the business cycle. J. Monet. Econ. 2014, 68, 68-85. [CrossRef]

10. Karnizova, L.; Li, J.C. Economic policy uncertainty, financial markets and probability of US recessions. Econ. Lett. 2014, 125, 261-265. [CrossRef]

11. Fernández-Villaverde, J.; Guerrón-Quintana, P.; Kuester, K.; Rubio-Ramírez, J. Fiscal Volatility Shocks and Economic Activity. Am. Econ. Rev. 2015, 105, 3352-3384. [CrossRef]

12. Bloom, N. Fluctuations in Uncertainty. J. Econ. Perspect. 2014, 28, 153-176. [CrossRef]

13. Leduc, S.; Liu, Z. Uncertainty shocks are aggregate demand shocks. J. Monet. Econ. 2016, 82, 20-35. [CrossRef]

14. Charles, A.; Darné, O.; Tripier, F. Uncertainty and the macroeconomy: Evidence from an uncertainty composite indicator. Appl. Econ. 2017, 50, 1093-1107. [CrossRef]

15. Bond, P.; Zhong, H. Buying High and Selling Low: Stock Repurchases and Persistent Asymmetric Information. Rev. Financ. Stud. 2016, 29, 1409-1452. [CrossRef]

16. Caglayan, M.; Jehan, Z.; Mouratidis, K. Asymmetric Monetary Policy Rules for an Open Economy: Evidence from Canada and the UK. Int. J. Financ. Econ. 2016, 21, 279-293. [CrossRef]

17. Hoang, T.H.V.; Lahiani, A.; Heller, D. Is gold a hedge against inflation? New evidence from a nonlinear ARDL approach. Econ. Model. 2016, 54, 54-66. [CrossRef] [PubMed]

18. Lacheheb, M.; Sirag, A. Oil price and inflation in Algeria: A nonlinear ARDL approach. Q. Rev. Econ. Financ. 2019, 73, 217-222. [CrossRef]

19. Arize, A.C.; Malindretos, J.; Igwe, E.U. Do exchange rate changes improve the trade balance: An asymmetric nonlinear cointegration approach. Int. Rev. Econ. Financ. 2017, 49, 313-326. [CrossRef]

20. Li, X.-L.; Li, L.; Si, D.-K. Asymmetric determinants of corporate bond credit spreads in China: Evidence from a nonlinear ARDL model. N. Am. J. Econ. Financ. 2019, 101109. [CrossRef]

21. Nyberg, H. A bivariate autoregressive probit model: Business cycle linkages and transmission of recession probabilities. Macroecon. Dyn. 2014, 18, 838-862. [CrossRef]

22. Chatterjee, U.K. Do stock market trading activities forecast recessions? Econ. Model. 2016, 59, 370-386. [CrossRef]

23. Brogaard, J.; Detzel, A.L. The asset-pricing implications of government economic policy uncertainty. Manag. Sci. 2015, 61, 3-18. [CrossRef]

24. Antonakakis, N.; Chatziantoniou, I.; Filis, G. Dynamic co-movements of stock market returns, implied volatility and policy uncertainty. Econ. Lett. 2013, 120, 87-92. [CrossRef]

25. Bijsterbosch, M.; Guerin, P. Characterizing very high uncertainty episodes. Econ. Lett. 2013, 121, $239-243$. [CrossRef]

26. Pástor, L.; Veronesi, P. Uncertainty about government policy and stock prices. J. Financ. 2012, 67, $1219-1264$. [CrossRef]

27. Pástor, L.; Veronesi, P. Political uncertainty and risk premia. J. Financ. Econ. 2013, 110, 520-545. [CrossRef]

28. Nakaota, H. The term structure of interest rates in Japan: The predictability of economic activity. Jpn. World Econ. 2005, 17, 311-326. [CrossRef]

29. Hayashi, F.; Prescott, E.C. The 1990s in Japan: A Lost Decade. Rev. Econ. Dyn. 2002, 5, 206-235. [CrossRef]

30. Shin, Y.; Yu, B.; Greenwood-Nimmo, M. Modelling Asymmetric Cointegration and Dynamic Multipliers in a Nonlinear ARDL Framework. In Festschrift in Honor of Peter Schmidt; Springer: New York, NY, USA, 2014; pp. 281-314.

31. Pesaran, M.H.; Shin, Y. An autoregressive distribute lag modeling approach to cointegration analysis. In Econometrics and Economic Theory in the 20th Century: The Ragnar Frisch Centennial Symposium; Chapter, 11; Strom, S., Ed.; Cambridge University Press: Cambridge, UK, 1999.

32. Pesaran, M.H.; Shin, Y.; Smith, R.J. Bounds testing approaches to the analysis of level relationships. J. Appl. Econom. 2001, 16, 289-326. [CrossRef] 
33. Schorderet, Y. Asymmetric Co-Integration; University of Geneva: Geneva, Switzerland, 2003.

34. Veronesi, P. Belief-Dependent Utilities, Aversion to State-Uncertainty and Asset Prices; Working Paper; University of Chicago: Chicago, IL, USA, 2001.

35. Li, X.-M.; Zhang, B.; Gao, R. Economic policy uncertainty shocks and stock-bond correlations: Evidence from the US market. Econ. Lett. 2015, 132, 91-96. [CrossRef]

36. Dickey, D.A.; Fuller, W.A. Distribution of the Estimators for Autoregressive Time Series with a Unit Root. J. Am. Stat. Assoc. 1979, 74, 427-431.

37. Phillips, P.C.B.; Perron, P. Testing for a Unit Root in Time Series Regression. Biometrika 1988, 75, $335-346$. [CrossRef]

38. Connolly, R.; Stivers, C.; Sun, L. Stock Market Uncertainty and the Stock-Bond Return Relation. J. Financ. Quant. Anal. 2005, 40, 161-194. [CrossRef]

(C) 2020 by the authors. Licensee MDPI, Basel, Switzerland. This article is an open access article distributed under the terms and conditions of the Creative Commons Attribution (CC BY) license (http://creativecommons.org/licenses/by/4.0/). 